Exploring the professional development needs of new teacher educators situated solely in school: pedagogical knowledge and professional identity

Elizabeth White

School of Education, University of Hertfordshire, Hatfield, Herts, UK

Dr E J White

School of Education

University of Hertfordshire

De Havilland Campus

Hatfield

Hertfordshire

AL10 9AB

e.j.white@herts.ac.uk 


\section{Exploring the professional development needs of new teacher educators situated solely in school: pedagogical knowledge and professional identity}

This paper investigates the experiences of secondary teachers within their workplace as they take on the role of leading subject knowledge development days for small groups of student teachers through a case study approach. Semi-structured interviews, the reflective journals of these teachers and the evaluations of the days by the student teachers were used as the data gathering methods; the teachers involved were 'conversational partners' in the research (Rubin and Rubin, 2005:14). Themes were recognized that characterized the developing perceptions and practices of these new teacher educators. The findings reveal a number of professional development needs of new teacher educators situated solely in school, some similar with those situated in Higher Educational Institutions (McKeon and Harrison, 2010) including fostering an understanding that modelling needs to be made explicit to student teachers (Lunenberg et al., 2007). This has important implications with the introduction of Teaching Schools with responsibilities for educating student teachers in England (DfE, 2010). Suggestions are shared for nurturing teachers taking on this additional role as they develop their new identity and professional knowledge and skills whilst not situated geographically within a local community of practice.

Keywords: modelling professional practice; explicit modelling; teacher education; community of practice; professional identity;

\section{Introduction}

This research focuses on the initial experiences and perceptions of two secondary teachers within their workplace as they take on the role of supporting student teachers in developing their subject knowledge for teaching. The aim was to understand the needs of experienced teachers in school when they take on this new responsibility, in order to provide for their effective professional development.

The student teachers attended three subject development days within the schools where the experienced teachers were working. The days were spread over the year. The teachers, Beatrice and Amanda, were given the freedom to choose the content, order and pedagogy for their sessions. These teachers were at different stages of their careers and had different prior experience of working with student teachers. Beatrice had trained to teach through a traditional postgraduate certificate in education route eight years ago. She was teaching in the same school that she joined as a newly qualified teacher. In her fourth year of teaching she took on responsibility as a head of subject. Recently her responsibility had grown to include other subjects and during the research she was head of a department. She has had experience of mentoring student teachers on different initial teacher training programmes, and has led short training sessions in subject knowledge in a Higher Education Institution. Amanda trained to teach through the graduate teacher programme four years ago. This is an employment-based route into teaching. She was teaching in the same school that she trained in. She had not been a mentor of student teachers. These teachers were chosen to participate in the research because this was the first year that they had led subject knowledge development days with student teachers.

The data revealed that these teachers drew on their personal experiences to plan their sessions. The initial tacit assumption of one teacher was that you only needed experience as a teacher to become a teacher educator. However this changed as both teachers developed their thinking during the year. 
With the UK Government's proposal to relocate some teacher education from Higher Education Institutions into schools in England (DfE, 2010), this study indicates issues that will need to be addressed with respect to supporting new teacher educators situated solely in school. The research shows that these experienced teachers have similar challenges to new teacher educators situated within Higher Education Institutions; however they may not be geographically situated within a community of practice to readily inform their methods and underpinning theory and to nurture the development of a new aspect to their identity.

\section{New Teacher Educators}

There are a growing number of studies on the professional learning of teacher educators (Murray and Male, 2005; Lunenberg et al., 2007; Swennen et al., 2008; Wood and Borg, 2010) but within this body of literature there is little about the transition from being a practising school teacher, to maintaining this role whilst additionally taking on the role of teacher educator. It is likely that there will be a growing number of teachers in England who will take on this additional role, with the Government's plans to increase school-based teacher training (DfE, 2010). Therefore it is important to explore the professional development needs of these new teacher educators.

Harrison and McKeon (2008) and Williams and Ritter (2010) purport that there is little formal preparation provided for the transition from teacher to teacher educator in the setting of Higher Education Institutions. This transition is not automatic and may involve a period of de-skilling whilst moving from expert in one field to novice in another (Berry and Loughran, 2002; Harrison and McKeon, 2008; Clemans et al., 2010; White, 2010). Murray and Male (2005) discuss the transition from teacher to teacher educator as a move from firstorder to second-order practice, i.e. from teaching to teaching about teaching. This research indicates that in Higher Education Institutions new teacher educators initially rely on knowledge and understanding of the classroom. After a time they realise that first-order practice is not sufficient for teaching student teachers about teaching, and that additional practices and knowledge of teacher education are needed. This occurs with a growing awareness of the needs of their learners and through professional and organisational socialisation.

Being a teacher educator involves different pedagogical knowledge from being a teacher. Murray and Male (2005) identified this as a crucial area for professional development of new teacher educators. Modelling is an important aspect of this, as the teacher educator is in a position to have a strong impact on the student teachers' views of teaching (Lunenberg et al., 2007). Explicit modelling can contribute to the professional development of the student teachers and improve the teaching of the teacher educators themselves. The importance of making tacit professional knowledge explicit to student teachers is vital to linking practice with theory. This is often lacking in the school setting where student teachers are observing experienced teachers who may not articulate their professional skills and knowledge or link them to educational theory. The challenge of developing explicit modelling as a pedagogical tool is described by Loughran and Berry (2005) and White (2010) and is explored further in Loughran (2006) and Russell and Loughran (2007).

McKeon and Harrison (2010) recognise that new teacher educators in Higher Education Institutions learn from formal and informal practices in their workplace and that early professional learning is facilitated by legitimate peripheral participation in the community of practice as described by Lave and Wenger (1991). When new teacher educators work alongside experienced teacher educators they move towards full participation in the community of practice and gain confidence and expertise. Lave and Wenger (1991) 
purport that professional identity is formed in a community of practice. Swennen et al. (2008) suggests that the professional identity of teacher educators is built in a socio-constructive way; this means that the new teacher educators that are involved in their own workplace may find it difficult to develop this identity, and may not even see themselves as teacher educators, since this is one role among many that they have in their workplace.

In order to understand the development of identity it can be helpful to use the idea of substantive and situational self. The substantive self is based on core beliefs, often formed through life experiences, which are used to define who you are, whereas the situational self is established through relationships around us, in our context, and may be adapted in new circumstances (Nias, 1989). Murray and Male (2005) consider the development of a new identity to be complete when the substantive and situational aspects of self are brought into line, even if that means some changes to the substantive self. At this point, the new teacher educator feels confident and competent in this role and feels satisfied with their performance. New teacher educators who are working solely in school may have opportunity to develop their situational self through the sessions they lead, and relating to the student teachers but may have less opportunity to develop their substantive self through engaging with other teacher educators to explore the full nature of the role.

Developing supportive professional relationships with other teacher educators and being part of a learning community will be important for these new teacher educators to develop their identity. Examples of how teacher educators learn from each other are described in Berry and Loughran (2002) where a novice teacher educator learns alongside a more experienced colleague through team teaching and in Schuck et al. (2008) where teacher educators learn through peer observation and professional conversation. These opportunities may prove challenging to provide for new teacher educators who are geographically isolated and have very limited time available for this type of learning, which could help develop their substantive self.

Through exploring the case studies of two teachers new to this role in school this paper considers the personal beliefs of these two teachers about how to educate student teachers, investigating their understanding of explicit modelling as a pedagogical tool. It then looks at the impact of this new role on the professional practice and identity of these experienced teachers and reflects on how a community of practice may be instrumental in developing professional knowledge and identity as teacher educators.

\section{Research Approach}

A case study approach was chosen to facilitate an in depth exploration of the experience of two teachers taking on a new role (Burton and Bartlett, 2009). This qualitative interpretive approach provided the opportunity to examine the thoughts, perceptions and beliefs of these teachers. Additionally, investigating how their understanding of the role developed whilst they prepared and worked with student teachers revealed some of the demands of this role and their needs as new teacher educators. The purpose of doing a case study was not to generalize but to look in detail on the uniqueness of the case itself which, through interpretation, may relate to other situations (Stake, 1995; Burton and Bartlett, 2009). The study and its conclusions form an exploratory enquiry. The rationale was to gain a rich and holistic understanding of these two cases that might inform the assistance provided for new teacher educators outside Higher Education Institutions. The research revealed insights into early experiences of becoming a teacher educator and how these teacher educators see their own identities developing.

Two cases were used to allow more confidence in the conclusions where the patterns matched in the data analysis (Yin, 2009). These teachers were chosen because this was the 
first year that they have had this new role. Both were working in their own school with a small group of student teachers (between two and four, all sharing the same subject specialism) and were outside the usual network of support for teachers working with this programme because of their different role in presenting the subject knowledge development days, rather than as mentors to individual student teachers.

\section{Data Collection}

Data was collected using three qualitative methods; semi-structured interviews, a reflective log completed over the period of the study and evaluations of the sessions by the student teachers. The first interviews took place between the first and second subject knowledge development days. This timing was to enable the teachers to speak from experience in the interview and not to be influenced by the researcher about how they led the first day. The second interviews were after the third (and last) subject knowledge development day and the reflective logs were collected for analysis at the same points. The responses in the interviews and the records within the logs were consistent. This supports the trustworthiness of the data (Yin, 2009). The accuracy of the transcripts and the interpretation was checked by the participants involved. Samples of the collected data were shared with colleagues in other research fields to verify the analysis and conclusions drawn and as a check against bias (Cohen et al., 2007; Yin, 2009).

The use of semi-structured interviews allowed the participants to introduce issues that were not raised in the interview, but which might be relevant to the research and it enabled participants to share their unique perceptions (Cohen et al., 2007). The questions were customized to make the teacher feel comfortable, using a 'responsive interviewing model' (Rubin and Rubin, 2005: 15). Pseudonyms have been used to ensure privacy of the teachers. The interviews were set up with the explicit aim beforehand to be supportive of the role that the teachers were undertaking (Cohen et al., 2007; Burton and Bartlett, 2009). The teachers were viewed as 'conversational partners' (Rubin and Rubin, 2005:14), and their involvement sought at each stage of the process, in order to build a constructive relationship (Wilson and Stutchbury, 2009). The open-ended nature of the questions and the intention to build a mutually safe and supportive environment gave interviewees some power over what was discussed and understanding was constructed together through the process (Oliver, 2003). Although the aim was to be non-interventionist, the interviews raised questions and options previously not considered by the teacher, which inevitably impacted their thinking regarding their new role. In this respect the research has become the story of a shared journey in developing this new aspect of a programme. In being non-judgemental in dealing with the teachers, in order to create a trusting relationship where openness and vulnerability is present, the interpretation of the data involves making judgements that might make the participants uncomfortable about their openness therefore the teachers were involved in dialogue over the analysis and conclusions too (Stake, 1995).

\section{Question design}

The initial section of the first interview was designed to review the teacher's experience as a teacher and a teacher educator, to discover if they had already had any experience or professional development to support them in this new role, as the literature reports a paucity of support for the transition between school teacher and teacher educator in Higher Education Institutions (Wood and Borg, 2010). This section provided the opportunity to discover some of the implicit values about teaching that these teachers are holding (Brant, 2006; Fisher et al., 2010). 
The second section started by exploring the feelings and beliefs that these teachers had about taking on this new role, and how their experience of the first session compared to their expectations. This could help to develop an understanding of how to support them in their professional development. This section also provided a description of events at the first day, and through doing so revealed the type of pedagogical strategies which they had chosen to use. Probing revealed the extent to which they were explicitly modelling practice for the student teachers.

The last section concluded with a discussion about the sort of support that these teachers might use for their professional development as new teacher educators, considering self-reflection and engagement in a professional learning community (Woolhouse and Cochrane, 2009).

The initial section of the second interview explored how the teacher's understanding of subject knowledge had developed through this experience. The second section reviewed their beliefs about how to teach student teachers and the third section considered their view of their own identity.

\section{Findings}

\section{Personal beliefs about teacher education}

Berry (2008) stated:

'The assumptions that we hold are beliefs that we take for granted about the world and how we and others function in it. It can be difficult to recognise our assumptions and we may feel uneasy examining them, even when we want to.'

The assumptions and choices of these teachers revealed some of their personal beliefs. Amanda realised the importance of modelling good practice:

A: "I think what they found particularly useful about the observations was looking at how you went about teaching it, so that was part of the pedagogy. It's not so much the subject content because what I was actually teaching ...they don't actually do - it was a different exam board."

Beatrice was aware that a lot of teacher knowledge is hidden from student teachers, and that student teachers become more aware of that once they are teaching themselves. (Eraut, 1994) proposed the need for student teachers to reflect upon their observations and experiences and link this with a growing body of professional knowledge that they are constructing during their training. Student teachers can mimic common practices without reflection on their effectiveness or fitness for purpose. Both of these new teacher educators had started to understand the need to make tacit knowledge more explicit to student teachers so that they could consider how experienced teachers think, but they had not deliberately thought about on how they could do this in their sessions.

A: "Yea, I don't think I realised that [you have to make things explicit] until I actually started doing this ..."

Beatrice modelled using ICT within her subject to enhance the learning. This promoted a discussion after the lesson that gave the student teachers confidence to be able to use similar strategies in their teaching and to be able to explain the way that learning was being supported. This way of teaching the subject was new to the student teachers: 
B: “They hadn't come across it. And actually one of them said, her mentor was quite sceptical about using ICT, I think for the reason that sometimes it is used in quite a ... tokenistic way. So she found it really useful to actually see the way in which something can be used to promote learning [in this subject] and she felt quite confident that she might be able to demonstrate to her mentor that it was being used in that way."

Beatrice wanted the demonstration of different strategies from those that the student teachers had observed in their own schools to help the student teachers develop criticality, rather than just to imitate the practices they had seen. This comment reveals a dynamic that new teacher educators may be unaware of, the need to help student teachers develop professional relationships with their colleagues. When encouraging student teachers to take risks and try out different approaches, this can challenge the existing practices in their schools, so student teachers may need to have some advice on how to negotiate these opportunities.

In sharing about teaching one aspect of her subject to the student teachers Amanda revealed during the interview that the subject matter and the way that it was taught could link with the child protection training those student teachers receive. As a new teacher educator she had not been aware of the need to make such links explicit, so that student teachers can understand the application of other aspects of their training to teaching their subject.

Both teachers drew on their personal experience of what had been helpful to them in their own teacher training and professional development. This aspect probably influenced how they planned the sessions more than what content was covered. Amanda had made a definite choice that the pedagogy was more important in these sessions than the content. She remembered when she was taught as an adult for her degree:

A: "most of it was listening to a lecture rather than getting involved in an activity yourself. I think the getting involved in an activity yourself is probably the bit that you learn more from." different:

Whereas her experience of taught sessions on the graduate teacher programme was

A: "And I found that discussing with other trainees, when I was training, particularly useful because you can bounce ideas off each other, and then you can go and put them into practice yourself, in your own school... Sometimes you do learn more from other people, because they come out with things that you've never even dreamed of doing."

This comment reveals the importance of relationships with peers for collaborative learning which is well established in the literature (for example see Parsons and Stephenson, 2005). When Beatrice was asked whether she thought that adults should be taught in lectures or if active learning is more appropriate for them she admitted that it was a challenging decision. Her answers reflected an inner conflict that she experienced in deciding between imparting her own knowledge to the student teachers or providing them opportunities to learn together:

B: "I think for teacher training it does still have to be a mix... I think it is really important that they get to hear the experiences that other people have and the way things work in different schools with different student teachers. And certainly in the sessions, they liked to share their experiences...they did also value the direct teaching input. They recognised that there were things that they didn't know and they really liked finding out about them." 
When reflecting on the strategies she used in her sessions, she had included some lecture-style input and some activities that she might use with pupils as well as modelling some practice whilst teaching her pupils for the student teachers to observe and reflect on. For her the priority was to reflect on what the student teachers could learn about using the activities with their pupils:

B: $\quad$ "I also did some activities that you would perhaps use in the classroom with pupils, some card sort activities; because I think it is quite good, you get ideas from that... You think through yourself "what did I find hard in that activity - so if you use it in the classroom ... what would I change?'... It was valuable for them to go through the process, and then think through how the pupils might respond to it."

In planning to have student teachers observing a lesson where they are seeking to model outstanding practice, the teachers make themselves vulnerable which can feel uncomfortable:

B: "The only disappointment with the day was that the lesson I taught and that they observed in the morning was quite poor (by my standards)! I did not enjoy having observers when I knew I was not modelling outstanding practice. However, the rest of the day was so successful and the trainees were so thankful and complementary about the day ... that I soon forgot about the disappointment of the observation. Hopefully, they just learned that we are all human and unfortunately, not all lessons can be outstanding in every aspect."

However when the teacher discussed the observations with the student teachers they were able to learn just as effectively in these circumstances and these opportunities were really appreciated by the student teachers in their evaluations of the sessions.

Beatrice planned to make sure that the implications for applying theory into practice were addressed adequately during the session:

B: $\quad$ "Too often I have left ... training feeling inspired by some aspect of educational theory but find that ... there is not time to incorporate it into practice or to work out how it might apply to my subject area or context." (Reflective log)

Beatrice had observed and reflected on the practice of new teachers in the classroom before leading these sessions, so she was aware of common mistakes of student teachers. She drew on this knowledge to inform her choice of material to cover in the sessions. She made choices about her own pedagogy that she used during the day, which may have reflected her own prior experience as an adult learner or her belief of what is expected of subject tutors. She assumed that the student teachers would have little classroom experience to discuss, so she chose not to devote too long to sharing. The planned activities in the session focussed on explaining, demonstration and guided instruction of tasks initially, possibly limiting the opportunities for social construction of subject knowledge. She shared that the student teachers did not ask many questions, but said they would like more group work. It could be helpful for new teacher educators to consider how they can model the enquiry process by equipping student teachers with questions that they could ask to critically evaluate theory and practice.

In summary, the new teacher educators believed that modelling good practice was important and they had a growing appreciation of the need to be explicit about the decisions they make about their teaching so that the student teachers could learn effectively from observations and activities. Some of the comments of the new teacher educators revealed aspects of their role that they had not appreciated fully and that could be explored further 
through involvement in a community of practice. This included their understanding of the wider aspects of their role in supporting student teachers in making links across their training and in developing effective relationships within their host schools.

\section{Impact of new role on teacher practice and identity}

Amanda is a successful teacher, with her subject being the most popular option in the school at Key Stage 4 and 5. She is enthusiastic about her subject.

A: "I really love teaching my subject, I think it’s brilliant."

Amanda was concerned about being younger than the student teachers, despite having four years of classroom experience.

A: "When you said about being an experienced teacher I still find that really funny! I still find that really, really strange, because I still don't see myself as that experienced."

Amanda felt anxious about leading the sessions, because it was outside her experience however she enjoyed the first session. The experience of leading the session started to challenge her view of herself from being inexperienced; to realising that she had a wealth of understanding that she could use reflectively to support the professional development of others.

Beatrice was much clearer in her view of her own identity in the area of leading the professional development of new teachers. She felt confident about taking on the role following eight years classroom experience and four years as a subject leader. She felt apprehensive about leading a full day but was really pleased with how it went. She focussed on the learning needs of student teachers as she made decisions about leading the session.

B: $\quad$ "I've also done ... a short session ... on teaching gifted and talented pupils. I was really pleased to take that and turn it into something which was a bit lengthier and weightier. And I think that the other thing that attracted me about it [i.e. leading the sessions] was that I can choose the key areas that I could do, because I think there are certain areas that I see in terms of the trainees coming through here [i.e. this school] where maybe they haven't had enough exposure, or common mistakes that are made, so I quite liked to be able to address what I thought those were in the sessions."

She did not experience the same degree of anxiety that Amanda had, being more secure in this identity already.

B: "And I kind of think that all the emotions and the concerns and the feelings of satisfaction that I had about it [leading the session] were feelings that I have had before."

Amanda reflected on the first session that she led and related it to her own teaching, using it to challenge her practice regarding making assumptions about prior learning and to consider more variety in her own teaching strategies. She also reflected about her own professional development needs whilst considering the areas that she was planning for future sessions. She revealed that she saw herself as a co-learner with the student teachers, using the experience to develop her as well as the student teachers.

A: "I have actually picked up some things that the trainees do that I wasn't expecting, I don't think, at the very, very start. But I have learnt a lot from them, in the same way that they have 
probably learnt a lot from me. I would probably say that it's been a two way process in that they are being trained and I have benefitted from it; how to go about teaching certain topics."

The realisation that she would need to model good practice during her sessions with respect to developing independent learners was implicit in the conversation with Amanda. Similarly there was an expectation that this would mean that she would have to develop her own practice.

Beatrice shared a similar theme through her reflective log, revealing her enthusiasm for her subject and her readiness to learn and develop her own practice further as a result of planning for the sessions. She recognised that the impact for her had been less on her classroom practice but more on her leadership role.

B: “... certainly in terms of where I want to take the department now and our new priorities. I think it has helped me to clarify that... much more, so it has been very useful in that sense."

At the end of the year the teachers discussed how they viewed themselves in the light of their experiences leading sessions for student teachers. Both had a strong sense of identity as a teacher.

B: $\quad$ "I know as one teaches for longer, ones career develops, you have different responsibilities for staff development and things like that. I still see myself as a teacher, and that still occupies a lot of my time and thought, in terms of...preparing for my lessons, making sure they are the quality they should be, and evaluating them as well."

Beatrice also recognised herself as a teacher educator, but Amanda did not accept the title of teacher educator currently.

A: "I think I still feel quite new to teaching in that respect...I did really, really enjoy it [leading the sessions]. It actually made me feel a lot more confident about my ability as a teacher ... [I] feel I can actually effectively ... teach other people about how to teach themselves, so yes, it is something that I would like to do, and I have even mentioned to the Head teacher about becoming an advanced skills teacher and the fact that I have enjoyed doing this sort of thing with the University"

Neither did Amanda want to be recognised as a leader of professional development in a broad sense, although she realised that was what she was currently doing.

A: "I suppose in some respects I have done [leading professional development], in regards to doing this, but in terms of a school, probably not, I still feel ... a little fish in a big pond. So in that case probably not, but in regards to the work I have done with you, then yes."

Beatrice welcomed being identified as a leader of professional development.

B: "Maybe increasingly so, I think, with the new roles that I am taking on with the school, particularly supporting other new heads of subject with their development. That is a big part of being a head of department, because I do everyone's performance review every year and help develop their job profile and try to make sure things are delegated in a way that people are able to develop professionally."

However Amanda felt comfortable with the prospect of being an academic, contributing to research and advancing our knowledge. 
A: "I would like to do some interesting research sometime...I did enjoy that aspect of my University degree - the final part of carrying out your own piece of research. Yes, that is something that I would consider."

But Beatrice did not identify with being an academic.

B: "When I think academic I would think of someone who is doing more than just the reading, but is spending time critically evaluating, formulating new ideas, and theories and opinions, and I am not sure how much I do of that."

These comments expose how Amanda and Beatrice see themselves in their new situations and how their views have developed during this initial transition period. Both teachers have benefited from their work as teacher educators as it has impacted their professional practice in the classroom and as a subject leader. Beatrice felt a more secure sense of identity as a teacher educator than Amanda because of her experiences in school and beyond. Both teachers expressed some vulnerability with the new role, in common with new teacher educators in Higher Education Institutions. In these institutions new teacher educators are expected to develop an academic identity by actively engaging with research, whereas those continuing as first order practitioners whilst developing as teacher educators may have other responsibilities and aspirations that could eclipse the development of an academic identity.

\section{Perceived professional development needs}

Initially Beatrice assumed that you only need experience as a teacher to become a teacher educator.

B: "I think it would be useful [to have some professional development for leading subject knowledge development sessions for student teachers], I guess it would be more useful for some people if they have never done that kind of thing. And then, you know, that obviously goes across the spectrum as people have had more experience, I suppose I have probably had a reasonable amount of experience."

However after the first session both teachers articulated that it would have been helpful to have some time to meet other teacher educators and to focus on some of the professional knowledge needed to lead the sessions.

B: "And also, you know, it's quite difficult in school to, even if you are sent things, to find the time to print them off and read them.... I think having even half a day to have someone talk it through and then you start your thinking. That's always useful."

A: $\quad$ "I think it probably would have been useful to work out where you are at, before you can ... help others, because then you can address the holes in your subject knowledge first."

Both teachers developed more understanding of their new role during the interview process, as they were able to explore in more depth about the pedagogy of teacher education and other features of this new aspect to their identity. This has been one of the strengths of employing the interviewing approach of (Rubin and Rubin, 2005) of developing 'conversational partners'. The comments of these new teacher educators indicate a desire to be engaged with the wider community of practice of teacher educators in order to develop confidence in their new role.

\section{Impact of this experience on the thinking and practice of these experienced teachers}




\section{Modelling as a pedagogical tool}

Through a survey of the research literature on teacher educators Swennen et al. (2010) identified modelling as a current theme, followed by an understanding that modelling alone is not enough to raise the understanding of student teachers to particular issues, and that the modelling needs to be made explicit to student teachers. McKeon and Harrison (2010) looked at what characterises the developing teaching practices of the new teacher educators and the ways that their professional learning develops. They recognised a change in focus from 'their teaching' to 'student teachers learning', not dissimilar to the change that can be observed in student teachers as they change their focus during their training from 'their teaching' to the 'pupils learning' (Fuller, 1970 in Eraut, 1994). Teacher educators working in Higher Education Institutions are not observed teaching pupils in school by their student teachers, so they are limited to enacting their pedagogy with the student teachers themselves (Loughran, 2007), whereas teacher educators in school can be observed with their classes, modelling their practice. However, wherever the modelling takes place, there needs to be an opportunity for the teacher educator to justify their pedagogical choices so that the student teachers can learn how experienced teachers think. In this research both teachers believed that it was important for teacher educators to model good practice, and for Amanda the 'how to teach' was more important than the 'what to teach'. This decision was not so clear cut for Beatrice. Their pedagogical ideas were drawn from their own experiences and personal preferences and their assumptions of what would be best for the student teachers. There was a growing awareness during the interview process of the need for experienced teachers to reveal their thinking to student teachers by explicitly modelling practice. In order to do this, experienced teachers need to have opportunities to reveal their thinking to themselves and to explore how to share this with student teachers rather than just 'telling them'. This is one area that involvement in a community of practice could support the professional development of these new teacher educators.

\section{Impact on professional practice and identity}

Teachers are adept in using all sorts of opportunities to develop their own professional practice and to make the best use of their time by using preparation to inform multiple aspects of their work. Both these teachers used the work they were doing as teacher educators to challenge their own practice, one regarding aspects of teaching and learning in her classroom and the other about leading the learning in her department.

Both participants had a secure teacher identity. Beatrice also viewed herself as a teacher educator and a leader of professional development at this point in her career. She was not undergoing a transition in her sense of professional identity through taking on this work as she had already some experience in a teacher education role. Amanda was developing a new aspect of her identity. She did not feel comfortable with the title of teacher educator or leader of professional development at this stage, but was able to 'grow into' the role through the year and felt positive about continuing in the role.

New teacher educators often experience a sense of being 'out of their depth' when making the transition from teacher to teacher educator based in Higher Education Institutions. This has been illustrated through practitioner research and self-studies (Murray and Male, 2005; Williams and Ritter, 2010; White, 2010). This feeling is linked in the literature to a sense of moving from 'expert' to 'novice' (Murray and Male, 2005); a realisation of the need to model good practice (Lunenberg et al., 2007) and a time of changing identity (Clemans et al., 2010). Loughran and Berry (2005) suggest that there can be a feeling of vulnerability for new teacher educators when endeavouring to develop a pedagogy of explicit modelling, and that this can be exacerbated by working alone and in isolation rather than in a supportive and 
collaborative community. Research by Clemans et al. (2010) revealed that teacher educators who are also currently practicing teachers and are working within their school settings to lead professional development felt a sense of loss from a perceived lack of experience in this role, feeling like imposters and losing their familiar professional self. Developing an identity as a teacher educator in their school, possibly working alone and in isolation from a community of practice is a complex task and carries considerable professional development needs to ensure rigorous and high quality initial teacher education into the future. Relationships with other teacher educators that are important for developing the substantive self may not be readily available.

Amanda felt she could identify with pursuing a more academic pathway alongside her teaching in the future, feeling this was a positive part of her own experience during her undergraduate years and because another member of her family was engaging in an academic career. Beatrice did not see herself as an academic, and doubted that this would be the path for her with the demands of her present role and the career pathway she was choosing. Scholarly and research activity is seen as an integral part of the work and professional knowledge of teacher educators' (Boyd et al., 2007). In the current economic climate the Higher Education landscape is shifting in England and the importance of teacher educators developing an academic identity is open to debate. If we are to develop excellent teachers who can inspire the current and future generations to reach their full potential it is crucial that teacher educators recognise and develop a strong sense of identity whatever contexts they work in. Teacher educators within universities are in the advantageous position of being part of an active academic community which informs their principles and practice and enables them to develop their professional voice. The question is how can new teacher educators in different contexts be integrated into an active academic community alongside other more experienced teacher educators, in order to support their new role. Higher Educational Institutions may need to work in new ways with schools to provide support of this nature.

\section{Implications for the professional development of new teacher educators}

The strategies that the participants used to prepare for their sessions included using 'in school training' and reading to get ideas and strategies which were critically evaluated through personal experience in the classroom. However neither teacher had other teacher educators readily available for them to discuss and develop their ideas and how they would use them with their student teachers. When teachers first become teacher educators they may be unaware of what they do not know about the professional knowledge and skills of teacher educators. Therefore they may be unlikely to seek out any specific training or support for this new role. Some of the responsibilities of being a teacher educator include being aware of broader educational issues for student teachers e.g. child protection issues and professional relationship issues. New teacher educators may not realise the necessity to incorporate these aspects into their teaching. Beatrice had considered aspects such as the need to link theory and practice, to develop the enquiry process in student teachers and to develop criticality, but she had limited ideas about how she was going to do this. This illustrates again the need for specific professional development opportunities for new teacher educators in these settings.

New teacher educators may draw on their own experience of being taught as a student teacher and of training that they have experienced as a qualified teacher when planning their own teaching methods. Opportunities to reflect on their personal beliefs and the influence of these on their practice and to explore their new identity could help them to develop their effectiveness. In retrospect both of these teachers felt that it would be helpful to have opportunities for specific professional development in order to prepare for this new role, 
realising themselves that their own experience as a teacher was insufficient alone. Teachers do not necessarily connect with advances in the research and theory of their profession (Loughran et al., 2003). The experience with these two teachers suggests that dialogue with other more experienced teacher educators may be more beneficial than providing relevant reading material to use independently.

\section{Discussion}

Research indicates that informal workplace settings provide effective professional learning for teacher educators, through interactions within a team of teacher educators providing a community of practice, as described by Lave and Wenger (1991), Harrison and McKeon (2008) and Boyd and Harris (2010). When teachers take on additional responsibility as teacher educators within their school, as may increasingly be the case with the development of Teaching Schools in England, it is challenging for them to engage with other teacher educators for professional development because of time restraints and distractions that draw their focus to the more immediate needs of their pupils. They may not be situated geographically within a community of practice of teacher educators where it is possible to share good practice, new initiatives, relevant educational research and theory. Murray and Male (2005) describe the process of establishing a new professional identity through professional socialisation enabling the new teacher educator to learn what it means to be a part of that profession. This reflects the socio-constructive way that professionals learn and a professional identity is formed (Swennen et al., 2008; Williams and Ritter, 2010). Clemans et al. (2010) ran a program to support leaders of professional development in their roles through establishing a professional learning community of peers where learning was collaborative. This provided an opportunity for these new teacher educators to develop their new identity as well as their practice and knowledge, which had not been an anticipated outcome.

New teacher educators, whether situated in a Higher Education Institution or another setting, need to develop a secure identity and to appreciate the need for explicitly modelling their practice, as well as developing other professional knowledge and skills. For those entering Higher Education Institutions there are induction procedures, which are reported to be inconsistent and in some cases inadequate because of an assumption by some that the knowledge and skills of teaching acquired in schools can be directly 'transferred' for teaching student teachers with few problems (Boyd et al., 2007). However, these teacher educators are situated geographically within a community of practice of other teacher educators and have opportunities to learn through legitimate peripheral participation. The situation is more complex for teachers who undertake the role of teacher educator situated within their own school or college of further education. Although they are situated within a community of practicing teachers, some of whom have responsibilities for the professional development of colleagues, it is less likely that there will be a similar focus on teacher learning as opposed to pupil learning. Also there is less opportunity to be part of an academic community contributing to international scholarship and research in education. These new teacher educators in schools need protected time with other more experienced teacher educators to nurture their development and reflect on their emerging practice (Boyd et al., 2011). It is of vital importance that the collaborative nature of the professional development of teacher educators should not be underestimated with the increase of Teaching Schools leading teacher education in England, as the quality of learning in the classroom depends on the quality of teacher early professional development. Clemans et al. (2010 p. 226) concluded:

"While it is important to share the 'what' and the 'how to' of teacher education, we must not overlook the significance of the "who am I' in this work." 
Providing opportunities to build relationships with other teacher educators can help to develop the substantive self to bring it in line with the situational self. Therefore it may be beneficial to develop learning communities for networking with other teacher educators who are at different stages in their careers. Specific areas that could be valuable to address include: reflecting on the needs of student teachers; looking at the pedagogy of teacher educators; developing scholarship and research; and to provide space for sharing their experiences of becoming teacher educators. Such opportunities could support the formation of this new aspect of their identity, as teacher educators.

\section{References}

BERRY, A. (Ed.) (2008) Learning about assumptions in leading Professional Learning, Melbourne, Australia, Department of Education and Early Childhood Development.

BERRY, A. \& LOUGHRAN, J. (2002) Developing an understanding of learning to teach in teacher education. IN LOUGHRAN, J. \& RUSSELL, T. (Eds.) Improving Teacher Education Practices through Self-study. London, RoutledgeFalmer.

BOYD, P., HARRIS, A. \& MURRAY, J. (2011) Becoming a Teacher Educator: guidelines for induction, Subject Centre for Education, ESCalate: The Higher Education Academy

BOYD, P. \& HARRIS, K. (2010) Becoming a university lecturer in teacher education: expert school teachers reconstructing their pedagogy and identity. Professional Development in Education, 36, 9-24.

BOYD, P., HARRIS, K. \& MURRAY, J. (2007) Becoming a teacher educator: guidelines for the induction of newly appointed lecturers in Initial Teacher Education, Subject Centre for Education, ESCalate: The Higher Education Academy.

BRANT, J. W. (2006) Subject knowledge and pedagogic knowledge: ingredients for good teaching? An English perspective. Edukacja, 94, 60-77.

BURTON, D. \& BARTLETT, S. (2009) Key issues for education researchers, London, Sage.

CLEMANS, A., BERRY, A. \& LOUGHRAN, J. (2010) Lost and found in transition: the professional journey of teacher educators. Professional Development in Education, $36,211-228$.

COHEN, L., MANION, L. \& MORRISON, K. (2007) Research Methods in Education, Oxford, Routledge Falmer.

DFE (2010) The Importance of Teaching: Schools White Paper.

ERAUT, M. (1994) Developing Professional Knowledge and Competence, London, Falmer.

FISHER, A., RUSSELL, K., MACBLAIN, S., PURDY, N., CURRY, A. \& MACBLAIN, A. (2010) Re-examining the culture of learning in ITE: engaging with the new demands of the 21st century. Critical and Reflective Practice in Education 2. Critical and reflective Practice in Education, 2, 92-102.

HARRISON, J. \& MCKEON, F. (2008) The formal and situated learning of beginning teacher educators in England: identifying characteristics for successful induction in the transition from workplace in schools to workplace in higher education. European Journal of Teacher Education, 31, 151 - 168.

LAVE, J. \& WENGER, E. (1991) Situated learning: Legitimate peripheral participation. , Cambridge, Cambridge University Press.

LOUGHRAN, J. (2006) Developing a pedagogy of teacher education: understanding teaching and learning about teaching, London, Routledge. 
LOUGHRAN, J. (2007) Enacting a pedagogy of teacher education. IN RUSSELL, T. \& LOUGHRAN, J. (Eds.) Enacting a pedagogy of teacher education. Values, relationships and practices. Abingdon, Routledge.

LOUGHRAN, J. \& BERRY, A. (2005) Modelling by teacher educators. Teaching and Teacher Education, 21, 193-203.

LOUGHRAN, J., MITCHELL, I. \& MITCHELL, J. (2003) Attempting to document teachers' professional knowledge. Journal of Qualitative Studies in Education, 16, 855-873.

LUNENBERG, M., KORTHAGEN, F. \& SWENNEN, A. (2007) The teacher educator as a role model. Teaching and Teacher Education, 23, 586-601.

MCKEON, F. \& HARRISON, J. (2010) Developing pedagogical practice and professional identities of beginning teacher educators. Professional Development in Education, 36, 25-44.

MURRAY, J. \& MALE, T. (2005) Becoming a teacher educator: evidence from the field. Teaching and Teacher Education 21, 125-142.

OLIVER, P. (2003) The student's guide to research ethics. Maidenhead, Open University Press.

PARSONS, M. \& STEPHENSON, M. (2005) Developing reflective practice in student teachers: collaboration and critical partnerships. Teachers and Teaching, 11, 95 - 116.

RUBIN, H. \& RUBIN, I. (2005) Qualitative Interviewing, The Art of Hearing Data, London, Sage.

RUSSELL, T. \& LOUGHRAN, J. (Eds.) (2007) Enacting a pedagogy of teacher education. Values, relationships and practices, Abingdon, Routledge.

SCHUCK, S., AUBUSSON, P. \& BUCHANAN, J. (2008) Enhancing teacher education practice through professional learning conversations. European Journal of Teacher Education, 31, 215 - 227.

STAKE, R. E. (1995) The art of case study research, London, Sage.

SWENNEN, A., JONES, K. \& VOLMAN, M. (2010) Teacher educators: their identities, subidentities and implications for professional development. Professional Development in Education, 36, 131-148.

SWENNEN, A., VOLMAN, M. \& VAN ESSEN, M. (2008) The development of the professional identity of two teacher educators in the context of Dutch teacher education. European Journal of Teacher Education, 31, 169 - 184.

WHITE, E. (2011) Working towards explicit modelling: experiences of a new teacher educator. Professional Development in Education, 37, 483-497.

WILLIAMS, J. \& RITTER, J. K. (2010) Constructing new professional identities through self-study: from teacher to teacher educator. Professional Development in Education, 36, 77 - 92.

WILSON, E. \& STUTCHBURY, K. (2009) Research design and ethics. IN WILSON, E. (Ed.) School-based research. A guide for education students. London, Sage.

WOOD, D. \& BORG, T. (2010) The rocky road: The journey from classroom teacher to teacher educator. Studying Teacher Education, 6, 17 - 28.

WOOLHOUSE, C. \& COCHRANE, M. (2009) Is subject knowledge the be all and end all? Improving Schools, 12, 160-173.

YIN, R. K. (2009) Case study research: design \& methods, London, Sage. 